\title{
Incidence and predictors of loss to follow-up among HIV infected adults after initiation of first line anti-retroviral therapy at University of Gondar comprehensive specialized Hospital Northwest Ethiopia, 2018: retrospective follow up study
}

Nebiyu Mekonnen ${ }^{1}$, Mohamed Abdulkadir ${ }^{1}$, Eleyias Shumetie ${ }^{1}$, Adhanom Gebreegziabher Baraki2 ${ }^{*}$ and Melaku Kindie Yenit ${ }^{2}$

\begin{abstract}
Objectives: The aim of this study was to estimate the incidence of lost to follow up from anti-retroviral therapy (ART) care and identify the associated factors among human immunodeficiency virus (HIV) infected patients after first-line ART initiation at University of Gondar comprehensive specialized hospital, Northwest Ethiopia between January 2012 and January 2018.

Results: The overall incidence rate of lost to follow up was 12.26 per 100 person years ( $95 \% \mathrm{Cl}(10.61-14.18)$ ). Being underweight $\left(<18.5 \mathrm{~kg} / \mathrm{m}^{2}\right)$ (AHR, 1.52,95\% Cl 1.01-2.28), jobless (AHR, 2.22, 95\% Cl 1.2-4.11), substance abuser (AHR, 1.84 95\% Cl 1.19-2.86), having sub-optimal adherence (fair/poor) (AHR 6.33, 95\% Cl (3.90-10.26)), not receiving isoniazid prophylaxis (AHR 2.47,95\% Cl (1.36-4.48)), ambulatory functional status (AHR 1.94, 95\% Cl (1.23-3.06)), having opportunistic infections (AHR, $1.7495 \% \mathrm{Cl} 1.11-2.72$ ), having CD4 count 201-349 cells/ $\mu \mathrm{L}$ (AHR 0.58, 95\% Cl $(0.38-0.88)$ ) were found to be significant predictors of lost to follow up from ART service.
\end{abstract}

Keywords: HIV, Antiretroviral therapy, Loss to follow up, Northwest Ethiopia

\section{Introduction}

Human immunodeficiency virus/acquired immunodeficiency syndrome (HIV/AIDS) is the greatest worldwide public health problem. Even though the disease has no cure the global scale-up of ART has contributed to full preventive and therapeutic benefits [1]. ART contributed to a $32 \%$ and $16 \%$ global decline in AIDS-related deaths

\footnotetext{
*Correspondence: adsh04@gmail.com

${ }^{2}$ Department of Epidemiology and Biostatistics, Institute of Public Health, College of Medicine and Health Sciences, University of Gondar, Gondar, Ethiopia

Full list of author information is available at the end of the article
}

and new HIV infections respectively between 2010 and $2016[1,2]$.

In 2015 World Health Organization (WHO) recommended "treat all policy" that all people living with HIV should start ART after confirmed HIV diagnosis and clinical assessment irrespective of WHO clinical stage or CD4 cell count [3]. Early initiation of ART provides maximal and durable viral load suppression, restore and preserve immune function, improve quality of life $[4,5]$, and prevent transmission [6].

According to the United States Agency for International Development (USAID) Fast-Track strategy 90\% of people on ART should achieve sustained viral suppression with good adherence and retention to ART follow 
up [7]. But poor retention in care and lost to follow-up (LTFU) are great challenges in achieving this target [1]. LTFU was also highly associated with early death [8-11].

A systematic review conducted in sub-Saharan Africa in 2010 determined LTFU as the most common cause of attrition from HIV care $(59 \%)$ followed by death $(41 \%)$ and median attrition at 12,24 and 36 months was $22.6 \%$, $25 \%$ and $29.5 \%$ respectively. Retention was also decreased from $86.1 \%$ at 6 months to $64.6 \%$ at 36 months [12].

Lost to follow up from HIV care was positively associated with young age $[9,13,14]$, male sex $[14,15]$ single marital status $[13,16]$, illiteracy $[13,16]$, long travel time to the clinic $[14,17]$, bedridden functional status $[18,19]$, presence of opportunistic infections (OIs) and opportunistic infection prophylaxis $[20,21]$ low CD4 count $[9,18$, 22] less advanced WHO clinical stage [21].

The magnitude of LTFU and the factors contributing can vary from place to place. Early identification of the magnitude and factors is important to identify the vital intervention areas and improve the life of people living with HIV (PLHIV) via improved viral suppression. Even though there are few studies done Ethiopia, the rate of LTFU and its major predictors are not identified in the study area. So this study will fill this information gap.

\section{Main text \\ Methods}

A retrospective follow up study was conducted among HIV infected adults on first line ART at University of Gondar comprehensive specialized Hospital Northwest Ethiopia from January 2012 to January 2018. The Hospital is located in Gondar town, $727.22 \mathrm{~km}$ far from Addis Ababa, the capital city of Ethiopia. Gondar University comprehensive specialized hospitals began free ART service provision in March 2005, and since then 14,375 PLHIV were enrolled for care and treatment.

A total of 569 adult patient charts that is above 15 year old were reviewed after selecting them by simple random sampling from the ART register used in the ART clinic.

Trained nurses collected the data using a structured data extraction tool. The data were collected from patient charts. Data about the initiation time of therapy, the time when there was LTFU, socio-demographic, behavioral, clinical, therapeutic and immunologic factors were collected. LTFU was considered when a patient is not seen at the clinic for at least 90 days (3 months) after the last missed appointment but not transferred out from the facility to another facility or died. Time to LTFU was the time interval between the dates of ART initiation to the last missed appointment. Adherence was measured as follow; Good adherence: $\geq 95 \%$ adherence that is, missing only 1 out of 30 doses or missing 2 from the 60 doses. Fair adherence: $85-94 \%$ adherence that is, missing 2-4 doses out of 30 tabs or 4 to 9 tablets from 60 doses. Poor adherence: less than $85 \%$ adherence that is, missing $\geq 5$ tablets out of 30 tabs or $>10$ tabs from 60 tabs [6]. Functional status of participants was assessed based on WHO criteria as follows. Working: able to perform usual work inside or outside home. Ambulatory: able to perform activity of daily living-ADL, Not able to work. Bedridden: not able to perform ADL [23]. Substance abuse was measured as any history of harmful or hazardous use of psychoactive substances, including alcohol and illicit drugs. Censored are patients who died while on treatment, transferred out, or who are not lost from follow up till the end of the study period.

After collection data was cleansed, coded and entered into Epi Info version 7. Then it was exported to STATA 14 for further analysis. Person-year of follow up was calculated by using the time interval between the date of ART initiation and the date of LTFU or date of censoring. The Kaplan-Meier method was used to estimate rates of LTFU at specific time after ART initiation and NelsonAalen method was used to generate a cumulative hazard function. In the bivariable analysis with Cox proportional hazards regression model we selected independent predictors for multivariable Cox proportional hazards regression at "P" value less than 0.2 . We used a stepwise backward selection procedure to identify socio-demographic and clinical independent predictors for LTFU at $\mathrm{P}<0.05$ adjusted hazard ratios (AHR) with $95 \%$ confidence interval was used as the measure of association.

\section{Results}

\section{Socio-demographic and behavioral characteristics}

A total of 569 adult patients were followed for median follow-up time of 32 months ( $\mathrm{QQR}=40$ ). Majority of the study participants 324 (60.1\%) were females. Large proportion 227 (39.9\%) of the participants were in the age category of 25-34 years. The majority 409 (71.9\%) of participants were urban dwellers and most 514 (90.3\%) were orthodox Christians. Of the total, 257 (45.2\%) were married and 201 (35.3\%) have attended primary education. The majority of participants 503 (88.4\%) disclosed their HIV status at least to one individual (Table 1).

\section{Baseline clinical characteristics}

Sixty-eight (12\%) of the participants were tuberculosis (TB) co-infected and $228(40 \%)$ had at least one OI at entry. Most of the participants 259 (45.5\%) were at WHO clinical stage of I and/or II. The other 206 (36\%) and 104 (18\%) were at WHO stage III and IV respectively. Four hundred twenty-six (75\%) were on active working functional status and the other $120(21.1 \%)$ and $23(4 \%)$ were ambulatory and bedridden respectively. The median CD4 count was $266(\mathrm{IQR}=277)$. The majority, 392 (69\%) of 
Table 1 Baseline socio-demographic characteristics of HIV patients on ART at University of Gondar compressive specialized Hospital ART clinic between January 2012 and January 2018

\begin{tabular}{|c|c|c|}
\hline Characteristics & Category & Frequency (\%) \\
\hline \multirow[t]{4}{*}{ Age in years } & $15-24$ & $68(12)$ \\
\hline & $25-34$ & $227(39.9)$ \\
\hline & $35-44$ & $192(33.7)$ \\
\hline & $>45$ & $82(14.4)$ \\
\hline \multirow[t]{2}{*}{ Sex } & Male & 227 (39.9) \\
\hline & Female & $342(60.1)$ \\
\hline \multirow[t]{4}{*}{ Marital status } & Married & $257(45.2)$ \\
\hline & Never married & $83(14.6)$ \\
\hline & Divorced & $159(27.9)$ \\
\hline & Widowed/separated & $70(12.3)$ \\
\hline \multirow[t]{3}{*}{ Religion } & Orthodox & $514(90.3)$ \\
\hline & Muslim & $45(7.9)$ \\
\hline & Protestant & $10(1.8)$ \\
\hline \multirow[t]{2}{*}{ Residence } & Urban & $409(71.9)$ \\
\hline & Rural & $160(28.1)$ \\
\hline \multirow[t]{4}{*}{ Educational status } & No education & $154(27.1)$ \\
\hline & Primary & $201(35.3)$ \\
\hline & Secondary & $142(25)$ \\
\hline & Tertiary & $72(12.7)$ \\
\hline \multirow[t]{5}{*}{ Occupations } & Government/NGOs employed & $108(19.0)$ \\
\hline & Self employed & $137(24.1)$ \\
\hline & Jobless & $106(18.6)$ \\
\hline & Daily labor & $94(16.5)$ \\
\hline & Housewife & $124(21.8)$ \\
\hline \multirow[t]{3}{*}{ Partner HIV status } & Negative & $42(8.1)$ \\
\hline & Positive & $181(35.0)$ \\
\hline & Unknown & $294(56.9)$ \\
\hline \multirow[t]{2}{*}{ HIV disclosure status } & Not disclosed & $66(11.6)$ \\
\hline & Disclosed & $503(88.4)$ \\
\hline
\end{tabular}

participants were on TDF-3TC-EFV (1e) regimen and in $45(8 \%)$ the original regimen was changed to other regimens due to various reasons mainly adverse drug reactions. Among the total, 159 (28\%) had sub-optimal (fair/ poor) adherence to ART.

\section{Incidence of LTFU}

Since the study is a dynamic cohort we have determined the incidence of LTFU by taking the denominator as person year (PY). We had a total of 569 participants who were followed for a total of 1484.11 PY. The overall incidence rate of LTFU was 12.26 per 100 person years (95\% CI (10.61-14.18)). The cumulative hazard estimate of LTFU has shown difference among different levels of adherence. The cumulative hazard of LTFU among

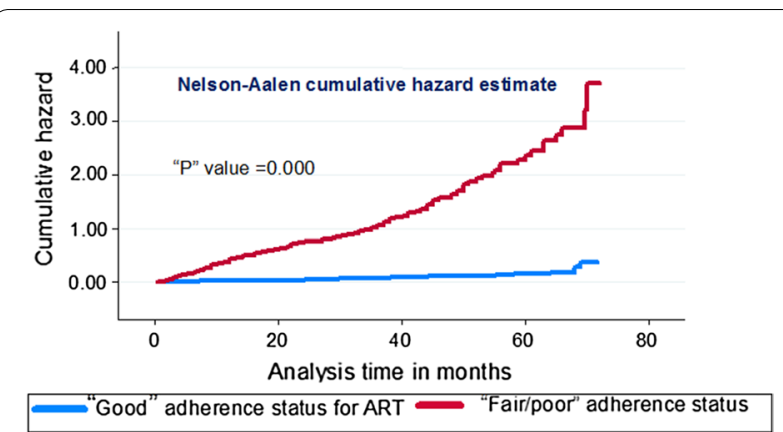

Fig. 1 Cumulative hazard estimate of LTFU after initiation of first line ART at University of Gondar comprehensive specialized hospital, Northwest Ethiopia between January 2012 and January 2018 by adherence status

participants with sub-optimal adherence status (fair/ poor) was higher than participants with good adherence status of ART (Fig. 1).

\section{Factors affecting lost to follow up from ART care}

According to the multivariable Cox regression analysis, underweight patients $\left(\mathrm{BMI}<18.5 \mathrm{~kg} / \mathrm{m}^{2}\right)$ were 1.52 times at higher risk of LTFU (AHR, 1.52, 95\% CI 1.01-2.28) as compared with $\mathrm{BMI} \geq 18.5 \mathrm{~kg} / \mathrm{m}^{2}$. Jobless participants were 2.22 times more likely to be LTFU (AHR, 2.22, 95\% CI 1.2-4.11). Participants who are substance abusers had $84 \%$ increased risk of LTFU as compared to their counter parts (AHR, 1.84 95\% CI 1.19-2.86). Participants with sub-optimal adherence status (fair/poor) had 6.33 times higher risk of LTFU (AHR 6.33, 95\% CI 3.90-10.26) than participants with good adherence. Participants with no Isoniazid (INH) prophylaxis were 2.47 times at risk of being loss to follow-up (AHR 2.47, 95\% CI (1.36-4.48)) than who received INH prophylaxis. Likewise, participants with ambulatory functional status were 1.94 times at higher risk of LTFU (AHR 1.94, 95\% CI (1.23-3.06)) than participants with working functional status. Participants who have OIs were 1.74 times (95\% CI 1.11-2.72) more likely to be lost to follow up as compared to their counter parts. When compared with participants with baseline CD4 count of less than 200 cells/ $\mu \mathrm{L}$, those who had $201-349$ cells $/ \mu \mathrm{L}$ were $42 \%$ less likely to be LTFU (AHR 0.58, 95\% CI (0.38-0.88)) (Table 2).

\section{Discussion}

The overall incidence of lost to follow up from ART care in our study was 12.26 per 100 person years. This finding is in line with other studies conducted in Gambella, Ethiopia [24] and South Ethiopia [25] but it was higher than a study conducted in Axum Ethiopia [26]. The LTFU incidence in our study is lower when compared 
Table 2 Predictors of LTFU among HIV infected patients after ART initiation in University of Gondar comprehensive specialized Hospital between January 2012 and January 2018

\begin{tabular}{|c|c|c|c|c|}
\hline Predictors & $\begin{array}{l}\text { Censored } \\
n=387\end{array}$ & $\begin{array}{l}\text { LTFU } \\
\mathrm{n}=182\end{array}$ & CHR $(95.0 \% \mathrm{Cl})$ & AHR $(95.0 \% \mathrm{Cl})$ \\
\hline \multicolumn{5}{|l|}{ Baseline CD4 cell } \\
\hline$<200$ & 138 & 78 & 1 & 1 \\
\hline $200-349$ & 120 & 51 & $0.65(0.45-0.92)$ & $0.58(0.38-0.88)^{*}$ \\
\hline $350-349$ & 64 & 36 & $1.14(0.76-1.69)$ & $1.37(0.86-2.20)$ \\
\hline$\geq 500$ & 65 & 17 & $0.75(0.44-1.28)$ & $1.10(0.58-2.07)$ \\
\hline \multicolumn{5}{|l|}{ INH prophylaxis } \\
\hline Yes & 143 & 17 & 1 & 1 \\
\hline No & 244 & 165 & $4.75(2.88-7.83)$ & $2.47(1.36-4.48)^{* *}$ \\
\hline \multicolumn{5}{|l|}{ Adherence status to ART } \\
\hline Good & 373 & 37 & 1 & 1 \\
\hline Fair/poor & 14 & 145 & $13.98(9.72-0.10)$ & $6.33(3.90-10.26)^{* * *}$ \\
\hline \multicolumn{5}{|l|}{ Baseline functional status } \\
\hline Working & 323 & 103 & 1 & 1 \\
\hline Ambulatory & 56 & 64 & $3.16(2.30-4.33)$ & $1.94(1.23-3.06)^{* *}$ \\
\hline Bedridden & 8 & 15 & $2.92(1.70-5.03)$ & $1.28(0.46-3.54)$ \\
\hline \multicolumn{5}{|l|}{$\mathrm{BMI}$} \\
\hline$\geq 18.5$ & 322 & 104 & 1 & 1 \\
\hline$<18.5$ & 65 & 78 & $2.82(2.10-3.79)$ & $1.52(1.01-2.28)^{*}$ \\
\hline \multicolumn{5}{|l|}{ Presence of Ols } \\
\hline No & 279 & 69 & 1 & 1 \\
\hline Yes & 108 & 113 & $3.04(2.25-4.12)$ & $1.74(1.11-2.72)^{*}$ \\
\hline \multicolumn{5}{|l|}{ Active TB } \\
\hline No & 367 & 134 & 1 & 1 \\
\hline Yes & 20 & 48 & $2.84(2.04-3.97)$ & $0.62(0.39-1.12)$ \\
\hline \multicolumn{5}{|l|}{ Substance use } \\
\hline No & 375 & 140 & 1 & 1 \\
\hline Yes & 12 & 42 & $7.12(4.99-0.16)$ & $1.84(1.19-2.86)^{* *}$ \\
\hline \multicolumn{5}{|l|}{ Occupations } \\
\hline Gov't/NGO employee & 84 & 24 & 1 & 1 \\
\hline Self employed & 101 & 36 & $1.37(0.82-2.30)$ & $2.08(0.96-3.79)$ \\
\hline Jobless & 76 & 30 & $1.68(0.98-2.88)$ & $2.22(1.20-4.11)^{*}$ \\
\hline Daily labor & 50 & 44 & $2.53(1.54-4.16)$ & $1.52(0.84-2.77)$ \\
\hline House wife & 76 & 48 & $1.84(1.13-3.01)$ & $1.24(0.68-2.24)$ \\
\hline \multicolumn{5}{|l|}{ Marital status } \\
\hline Married & 194 & 68 & 1 & 1 \\
\hline Never married & 52 & 31 & $2.10(1.37-3.23)$ & $1.73(0.99-3.02)$ \\
\hline Divorced & 104 & 55 & $1.72(1.20-2.47)$ & $1.37(0.88-2.14)$ \\
\hline Widowed/separated & 37 & 28 & $1.59(1.04-2.44)$ & $1.32(0.80-2.17)$ \\
\hline \multicolumn{5}{|l|}{ HIV disclosure status } \\
\hline Disclosed & 363 & 140 & 1 & 1 \\
\hline Not disclosed & 24 & 42 & $2.78(1.97-3.93)$ & $1.19(0.77-1.85)$ \\
\hline \multicolumn{5}{|l|}{ Psychiatric illness } \\
\hline No & 374 & 155 & 1 & 1 \\
\hline Yes & 13 & 27 & $4.52(3.15-6.48)$ & $0.82(0.54-1.26)$ \\
\hline
\end{tabular}

${ }^{* * * \mathrm{P}}<0.001,{ }^{* * \mathrm{P}}<0.01 * \mathrm{P}<0.05$ 
with several other studies conducted in Kenya [27], South Africa [28], Guinea-Bissau [29], Cameroon [17], India [30], Latin America and Caribbean [31].

In this study underweight patients were found to be at higher risk of LTFU. This is in line with a study conducted in West Africa, Guinea-Bissau [29] The possible reason as stated by a qualitative study could be many participants who cannot eat regularly, malnourished, drop out of care because of believing that "medication without proper food is ineffective or even harmful" [18].

Jobless patients have an increased risk of being LTFU when compared with government/NGO employees. This could be due to lack of money for transport fee, food, etc. which may discourage regular follow-up of ART. Joblessness or unemployment may also represent a marker of more advanced illness [32].

Patients who are substance abusers are more likely to be LTFU which is consistent with another study conducted in Ethiopia [19]. This is because substance use causes negligence and in general decreases the patients' tendency of receiving and taking the drugs appropriately [33].

Patients with suboptimal adherence were at an increased risk of being lost to follow up when compared with those with good adherence. This was supported by studies conducted in Nigeria [16] and Vietnam [34]. The possible reason could be patients with sub-optimal adherence may have socio-demographic and clinical problems that affect their adherence initially which further affect retention in care [35].

Patients who do not take INH prophylaxis were found to be at higher risk of LTFU. This was consistent with other studies [20,21,25]. This could be due to the direct effect of Isoniazid in preventing active tuberculosis, which in turn improves the quality of life of patients which leads to a longer stay in the treatment.

This study showed ambulatory patients to be at an increased risk of being LTFU as compared with working participants. This finding is consistent with study done in Nigeria [36] but another study showed a contrasting result [21]. The possible reason that ambulatory patients are more likely to be LTFU could be due to the social, economical, and financial influences that are caused by their inability to work. Thus may affect their stay in treatment.

Patients who had different opportunistic infections were at higher risk of being LTFU. This result is in line with other studies conducted in Uganda [37] and Togo [15]. This may be because of the pill burden, adverse drug toxicities, and interactions among OI treatment and ART, which demands a high commitment to follow all the medications.
When compared with patients with baseline CD4 count of less than 200 cells/ $\mu \mathrm{L}$, those who had 201-349 cells/ $\mu \mathrm{L}$ were $42 \%$ less likely to be LTFU. This finding was consistent with other several studies [21, 38, 39]. This might be the fact that an increment in CD4 count improves the immunity of patients and their wellbeing in general which will help them stay on treatment.

\section{Conclusions}

Lost to follow up in the study area was low. Factors that tend to deteriorate the life of patients like malnutrition, OIs, CD4 count below 200 cells $/ \mu \mathrm{L}$, and having suboptimal adherence to ART, ambulatory functional status, being substance abuser and not receiving Isoniazid prophylaxis were significantly associated with LTFU. Therefore clinicians shall consider the identified risk factors while giving ART service and counseling to decrease LTFU.

\section{Limitations}

Since we used secondary data we were not able to include some important variables like distance from the health facility that may affect LTFU.

\begin{abstract}
Abbreviations
ADL: activity of daily living; AHR: adjusted hazard ratio; AIDS: acquired immunodeficiency syndrome; ART: anti-retroviral therapy; BMI: body mass index; $\mathrm{Cl}$ : confidence interval; HAART: highly active antiretroviral therapy; HIV: human immunodeficiency virus; INH: isoniazid prophylaxis; IQR: inter-quartile range; LTFU: lost to follow up; NGO: Non-governmental Organization; Ols: opportunistic infections; PLHIV: people living with human immunodeficiency virus; PY: person year of observation; USAID: United States Agency for International Development; WHO: World Health Organization.
\end{abstract}

\section{Authors' contributions}

$\mathrm{NM}, \mathrm{MA}, \mathrm{ES}, \mathrm{AGB}$ and $\mathrm{MKY}$ have actively participated during conception and design, acquisition of data, or analysis and interpretation of data. All authors read and approved the final manuscript.

\section{Author details \\ ${ }^{1}$ School of Medicine, College of Medicine and Health Sciences, University of Gondar, Gondar, Ethiopia. ${ }^{2}$ Department of Epidemiology and Biostatistics, Institute of Public Health, College of Medicine and Health Sciences, University of Gondar, Gondar, Ethiopia.}

\section{Acknowledgements}

We would like to thank University of Gondar comprehensive specialized Hospital ART clinic staffs, especially data managers and porters working in medical record room who helped us during data collection.

\section{Competing interests}

The authors declare that they have no competing interests.

\section{Availability of data and materials}

The data upon which the results are based could be accessed based on a reasonable request made to the corresponding author.

Consent for publication

Not applicable. 


\section{Ethical approval and consent to participate}

The study was approved by University of Gondar College of medicine and health sciences, School of medicine research ethics review committee. To maintain confidentiality personal identifiers of patients were not collected.

\section{Funding}

Not applicable.

\section{Publisher's Note}

Springer Nature remains neutral with regard to jurisdictional claims in published maps and institutional affiliations.

Received: 27 November 2018 Accepted: 22 February 2019 Published online: 28 February 2019

\section{References}

1. UNAIDS. Ending AIDS progress towards the 90-90-90 targets: GlobaL AIDS update. Geneva: UNAIDS.org; 2017.

2. UNAIDS. Joint United Nations Programme on HIV/AIDS (UNAIDS) data. 2017. contract no: UNAIDS/JC2910E.

3. WHO. Guideline on when to start antiretroviral therapy and prophylaxis for HIV. Geneva: World Health Organization; 2015.

4. Ministry of Health, Ethiopia. National comprehensive HIV prevention, care and treatment training for health care providers participant manual. 2017.

5. Adult antiretroviral treatment guidelines [database on the Internet]. 2017

6. Cohen MS, Chen YQ, McCauley M, Gamble T, Hosseinipour MC, Kumarasamy N, et al. Antiretroviral therapy for the prevention of HIV-1 transmission. N Engl J Med. 2016;375(9):830-9.

7. Joint United Nations Programme on HIV/AIDS. Fast-track: ending the AIDS epidemic by 2030. Geneva: UNAIDS. 2014.

8. Brinkhof MW, Pujades-Rodriguez M, Egger M. Mortality of patients lost to follow-up in antiretroviral treatment programmes in resourcelimited settings: systematic review and meta-analysis. PLoS ONE. 2009;4(6):e5790.

9. Van Cutsem G, Ford N, Hildebrand K, Goemaere E, Mathee S, Abrahams $\mathrm{M}$, et al. Correcting for mortality among patients lost to follow up on antiretroviral therapy in South Africa: a cohort analysis. PLOS ONE. 2011;6(2):e14684

10. Fox MP. Retention of adult patients on antiretroviral therapy in lowand middle-income countries: systematic review and meta-analysis 2008-2013. J Acquir Immune Defic Syndr. 2015;69(1):98.

11. Wubshet M, Berhane $Y$, Worku A, Kebede $Y$. Death and seeking alternative therapy largely accounted for lost to follow-up of patients on ART in northwest Ethiopia: a community tracking survey. PLOS ONE. 2013;8(3):e59197.

12. Fox MP, Rosen S. Patient retention in antiretroviral therapy programs up to three years on treatment in sub-Saharan Africa, 2007-2009: systematic review. Trop Med Int Health. 2010;15(s1):1-15.

13. Alvarez-Uria G, Naik PK, Pakam R, Midde M. Factors associated with attrition, mortality, and loss to follow up after antiretroviral therapy initiation: data from an HIV cohort study in India. Glob Health Action. 2013;6:21682 (Epub 2013/09/14).

14. Ochieng-Ooko V, Ochieng D, Holdsworth M, Sidle JE, Wools-Kaloustian $K$, Braitstein $P$, et al. Influence of gender on loss to follow-up in a large HIV treatment programme in western Kenya. Bull World Health Organ. 2010:88:681-8.

15. Saka B, Landoh DE, Patassi A, d'Almeida S, Singo A, Gessner BD, et al. Loss of HIV-infected patients on potent antiretroviral therapy programs in Togo: risk factors and the fate of these patients. Pan Afr Med J. 2013:15:35 (Epub 2013/09/07)

16. Agbaji OO, Abah IO, Falang KD, Ebonyi AO, Musa J, Ugoagwu P, et al. Treatment discontinuation in adult HIV-infected patients on first-line antiretroviral therapy in Nigeria. Curr HIV Res. 2015;13(3):184-92 (Epub 2015/05/20)
17. Bekolo CE, Webster J, Batenganya M, Sume GE, Kollo B. Trends in mortality and loss to follow-up in HIV care at the Nkongsamba Regional hospital, Cameroon. BMC Res Notes. 2013;6(1):512 (Epub 2013/12/07)

18. Tiruneh YM, Galárraga $O$, Genberg B, Wilson IB. Retention in care among HIV-infected adults in Ethiopia, 2005-2011: a mixed-methods study. PLOS ONE. 2016;11(6):e0156619.

19. Gesesew HA, Ward P, Hajito KW, Feyissa GT, Mohammadi L, Mwanri L. Discontinuation from antiretroviral therapy: a continuing challenge among adults in HIV care in Ethiopia: a systematic review and metaanalysis. PLoS ONE. 2017;12(1):e0169651.

20. Dessalegn M, Tsadik M, Lemma H. Predictors of lost to follow up to antiretroviral therapy in primary public hospital of Wukro, Tigray, Ethiopia: a case control study. J AIDS HIV Res. 2015;7(1):1-9.

21. Berheto TM, Haile DB, Mohammed S. Predictors of loss to follow-up in patients living with HIV/AIDS after initiation of antiretroviral therapy. N Am J Med Sci. 2014;6(9):453-9.

22. Megerso A, Garoma S, Eticha T, Workineh T, Daba S, Habtamu Z, et al. Predictors of loss to follow-up in antiretroviral treatment for adult patients in the Oromia region, Ethiopia. HIV/AIDS Res Palliat Care. 2016:8:83-92.

23. National AIDS Control Organization (NACO) MoHFW, Government of India. ART-patient treatment Record. Feb. 2007.

24. Assemie MA, Muchie KF, Ayele TA. Incidence and predictors of loss to follow up among HIV-infected adults at Pawi General Hospital, northwest Ethiopia: competing risk regression model. BMC Res Notes. 2018;11(1):287

25. Teshome W, Belayneh M, Moges M, Mekonnen E, Endrias M, Ayele S, et al. Do loss to follow-up and death rates from ART care vary across primary health care facilities and hospitals in south Ethiopia? A retrospective follow-up study. HIV AIDS. 2015;7:167-74.

26. Tadesse K, Haile F. Predictors of loss to follow up of patients enrolled on antiretroviral therapy: a retrospective cohort study. AIDS Clin Res. 2014;5:12.

27. Ojwang'V, Penner J, Blat C, Agot K, Bukusi EA, Cohen C. Loss to followup among youth accessing outpatient HIV care and treatment services in Kisumu, Kenya. AIDS Care. 2016;28(4):500-7.

28. Mberi MN, Kuonza LR, Dube NM, Nattey C, Manda S, Summers R. Determinants of loss to follow-up in patients on antiretroviral treatment, South Africa, 2004-2012: a cohort study. BMC Health Serv Res. 2015; 15:259.

29. Hønge BL, Jespersen S, Nordentoft PB, Medina C, da Silva D, da Silva ZJ, Østergaard L, Laursen AL, Wejse C, Bissau HIV cohort study group. Loss to follow-up occurs at all stages in the diagnostic and follow-up period among HIV-infected patients in Guinea-Bissau: a 7-year retrospective cohort study. BMJ Open. 2013;3(10):e003499.

30. Blutinger EJ, Solomon S, Srikrishnan AK, Thamburaj E, Kumarasamy N, Balakrishnan $\mathrm{P}$, et al. Dropout from care among HIV-infected patients enrolled in care at a tertiary HIV care center in Chennai, India. AIDS Care. 2014:26(12):1500-5.

31. Carriquiry G, Fink V, Koethe JR, Giganti MJ, Jayathilake K, Blevins M, et al. Mortality and loss to follow-up among HIV-infected persons on long-term antiretroviral therapy in Latin America and the Caribbean. J Int AIDS Soc. 2015;18:20016 (Epub 2015/07/15)

32. Bassett WB IV, Chetty S, Mazibuko M, Bearnot B, Giddy J, Lu Z, Losina E, Walensky RP, Freedberg KA. Loss to care and death before antiretroviral therapy in Durban, South Africa. J Acquir Immune Defic Syndr. 2009:51(2):135

33. Chander G, Lau B, Moore RD. Hazardous alcohol use: a risk factor for non-adherence and lack of suppression in HIV infection. J Acquir Immune Defic Syndr (1999). 2006:43(4):411-7.

34. Tran DA, Ngo AD, Shakeshaft A, Wilson DP, Doran C, Zhang L. Trends in and determinants of loss to follow up and early mortality in a rapid expansion of the antiretroviral treatment program in Vietnam: findings from 13 outpatient clinics. PLoS ONE. 2013:8(9):e73181.

35. Fonsah JY, Njamnshi AK, Kouanfack C, Qiu F, Njamnshi DM, Tagny CT, et al. Adherence to antiretroviral therapy (ART) in Yaounde-Cameroon: association with opportunistic infections, depression, ART regimen and side effects. PLoS ONE. 2017;12(1):e0170893 (Epub 2017/02/01).

36. Odafe S, Idoko O, Badru T, Aiyenigba B, Suzuki C, Khamofu H, Onyekwena O, Okechukwu E, Torpey K, Chabikuli ON. Patients' demographic and clinical characteristics and level of care associated with lost to 
follow-up and mortality in adult patients on first-line ART in Nigerian hospitals. J Int AIDS Soc. 2012;15(2):17424.

37. Asiimwe S, Kanyesigye M, Bwana B, Okello S, Muyindike W. Predictors of dropout from care among HIV-infected patients initiating antiretroviral therapy at a public sector HIV treatment clinic in sub-Saharan Africa. BMC Infect Dis. 2016;16:43.

38. Melaku Z, Lamb MR, Wang C, Lulseged S, Gadisa T, Ahmed S, et al. Characteristics and outcomes of adult Ethiopian patients enrolled in
HIV care and treatment: a multi-clinic observational study. BMC Public Health. 2015;15:462 (Epub 2015/05/03).

39. Bucciardini R, Fragola V, AbegazT, Lucattini S, Halifom A, Tadesse E, et al. Predictors of attrition from care at 2 years in a prospective cohort of HIVinfected adults in Tigray, Ethiopia. BMJ Glob Health. 2017;2(3):e000325 (Epub 2017/10/31).
Ready to submit your research? Choose BMC and benefit from:

- fast, convenient online submission

- thorough peer review by experienced researchers in your field

- rapid publication on acceptance

- support for research data, including large and complex data types

- gold Open Access which fosters wider collaboration and increased citations

- maximum visibility for your research: over $100 \mathrm{M}$ website views per year

At BMC, research is always in progress.

Learn more biomedcentral.com/submissions 